\title{
Drugs Loaded into Electrospun Polymeric Nanofibers for Delivery
}

Erick José Torres-Martínez ${ }^{1,2}$, Graciela Lizeth Pérez-González ${ }^{1,2,3}$, Aracely Serrano-Medina ${ }^{1,4}$, Daniel Grande ${ }^{5}$, Ricardo VeraGraziano $^{6}$, José Manuel Cornejo-Bravo ${ }^{1,2}$, Luis Jesús Villarreal-Gómez ${ }^{1,2,3}$

${ }^{1}$ Universidad Autónoma de Baja California, Tijuana, Baja California, Mexico; ${ }^{2}$ Facultad de Ciencias Químicas e Ingeniería. Calzada Universidad \#14418, Universidad Autónoma de Baja California, Parque Industrial Internacional Tijuana, 22390 Tijuana, Baja California, Mexico; ${ }^{3}$ Escuela de Ciencias de la Ingeniería y Tecnología, Universidad Autónoma de Baja California, Blvd Universitario 1000. Valle de las Palmas, 22260. Tijuana, Baja California, Mexico; ${ }^{4}$ Facultad de Medicina y Psicología, Calzada Universidad 14418, Universidad Autónoma de Baja California, Parque Industrial Internacional Tijuana, 22390. Tijuana, Baja California, Mexico; ${ }^{5}$ Institut de Chimie et des Matériaux Paris-Est, UMR CNRS-Université Paris-Est Créteil, 2 Rue Henri Dunant, 94320 Thiais, France; ${ }^{6}$ Instituto de Investigación en Materiales, Universidad Nacional Autónoma de Mexico, Circuito Exterior S/N Circuito de la Investigación Científica, C.U., 04510 Ciudad de México, CDMX, Mexico.

Received, May 23, 2019; Revised, July 8, 2019; Accepted, July 9, 2019; Published, July 10, 2019.

ABSTRACT - The electrospinning technique is a useful and versatile approach for conversion of polymeric solutions into continuous fibers, ranging from a few micrometers $(10-100 \mu \mathrm{m})$ to the scale of nanometers $(10$ $100 \mathrm{~nm}$ ) in diameters. This technique can be used in a vast number of polymers, in some cases after modifying them to the required properties. The high surface-to-volume ratio of the fibers can improve some processes like cell binding and proliferation, drug loading, and mass transfer processes. One of the most important and studied areas of electrospinning is in the drug delivery field, for the controlled release of active substances ranging from antibiotics and anticancer agents, to macromolecules such as proteins and DNA. The advantage of this method is that a wide variety of low solubility drugs can be loaded into the fibers to improve their bioavailability or to attain controlled release. This review presents an overview of the reported drugs loaded into electrospun polymeric nanofibers to be used as drug delivery systems. These drugs are classified by their applications in pharmacy.

\section{INTRODUCTION}

One of the main strategies in drug delivery application is the controlled release of important biomolecules using fast dissolution of biodegradable polymers, because the used of these molecules allows the increment of drug solubility and bioavailability and it can be manipulated the rate and site of the drug delivery. It has been reported many drug delivery systems that are administered by enteral routes, such as tablets, capsules, granules; or the administration by parenteral routes, such as intravenous, intra-arterial, intramuscular and subcutaneous. These have some disadvantages, such as first-pass metabolism, discomfort or pain (1).

An alternative method for these types of release is loading pharmaceutical components into fibers by the electrospinning technique, since this is a method that produces ultra-fine fibers with controlled surface morphology. Using polymeric fibers, the different controlled-release administration routes allows the application of pharmaceutical drugs once or twice a day, improving the patient willingness and reducing the toxic plasma peak concentrations that can be produced by multiple administration of immediate release formulations (2).

Many advantages are obtained when the diameters of the polymeric fiber are reduced to micrometers or nanometers, such as a bigger surface area to volume ratio, elasticity and better mechanical properties (stiffness and resistance to traction), compared to any other known form of the material. These properties make polymer nanofibers the optimum candidates for many important applications in the biomedical areas (1-3).

Corresponding Authors: Luis Jesús Villarreal Gómez: luis.villarreal@uabc.edu.mx. Escuela de Ciencias de la Ingeniería y Tecnología, Universidad Autónoma de Baja California, Tijuana, Mexico. Blvd. Universitario \#1000. Unidad Valle de las Palmas. Tijuana, Baja California, México. ORCID ID: orcid.org/0000-0002-4666-1408; José Manuel Cornejo Bravo: jmcornejo@uabc.edu.mx. Universidad Autónoma de Baja California, Facultad de Ciencias Químicas e Ingeniería, Calzada Universidad 14418, Parque Industrial Internacional, Tijuana Baja California, Mexico. ORCID ID: 0000-0002-00138937. 


\section{Electrospinning}

The term electrospinning is derived from "electrostatic yarn" and it is a dry spinning process, which utilizes electrostatic forces to draw small fibers $(10-100 \mu \mathrm{m}$ to $10-100 \mathrm{~nm})$ from a polymer solution, or in its case, a melted polymer (4).

Figure 1 illustrates the basic configuration for the electrospinning device. It consists of three main components: a high voltage source, a syringe pump and a conductive collector.

The dissolved or molten polymer is housed in a syringe and placed in a syringe pump. When a droplet of the polymer solution appears on the tip of the metal needle a high voltage is applied (usually from $5 \mathrm{kV}$ to $50 \mathrm{kV}$ ), to the droplet hanging. This droplet will become highly electrified and the induced charges will be evenly distributed over the surface. The liquid drop will deform into a conical object known as the "Taylor cone". This cone appears when the space between the electrical conducting liquid and insulator exceeds a critical voltage, making the liquid drop unstable and transforming from a rounded shape to a conical shape $(5,6)$. When the voltage exceeds a threshold value, the electric force exceeds the surface tension of the drop and then one or more jets loaded with the solution are expelled from the tip of the drop, depending on the electric field strength. As the jet travels to a metal collector (usually a conductive one, like aluminum), the solvent evaporates and a nonwoven scaffold is formed on the collector surface $(7,8)$.

\section{Applications of the electrospinning technique}

Various drug delivery systems have been, and are currently being investigated, nanoscale formulations like liposomes, polymer micelles, some complexes, and nanofibers have attracted special attention during these last decades, this is because these systems have the potential to improve the therapeutic effects and reduce the toxicity of conventional dosage forms. Some of the attractive features for an ideal drug delivery system would be high loading capacity, high encapsulation efficiency, simultaneous delivery of various therapies, ease of operation and cost-effectiveness, either for immediate or extended release. Some other uses may also be wound dressing and local chemotherapy. In comparison to other formulations, the electrospinning technique is very versatile in the selection of its materials and pharmaceutical drugs for their application of the release of these, so this makes it an attractive technique for the area of drug delivery systems.

In the case of drug delivery systems, drug-loaded nanofibers deliver continuously the drug meanwhile the nanofiber are in degradation (Figure 2).

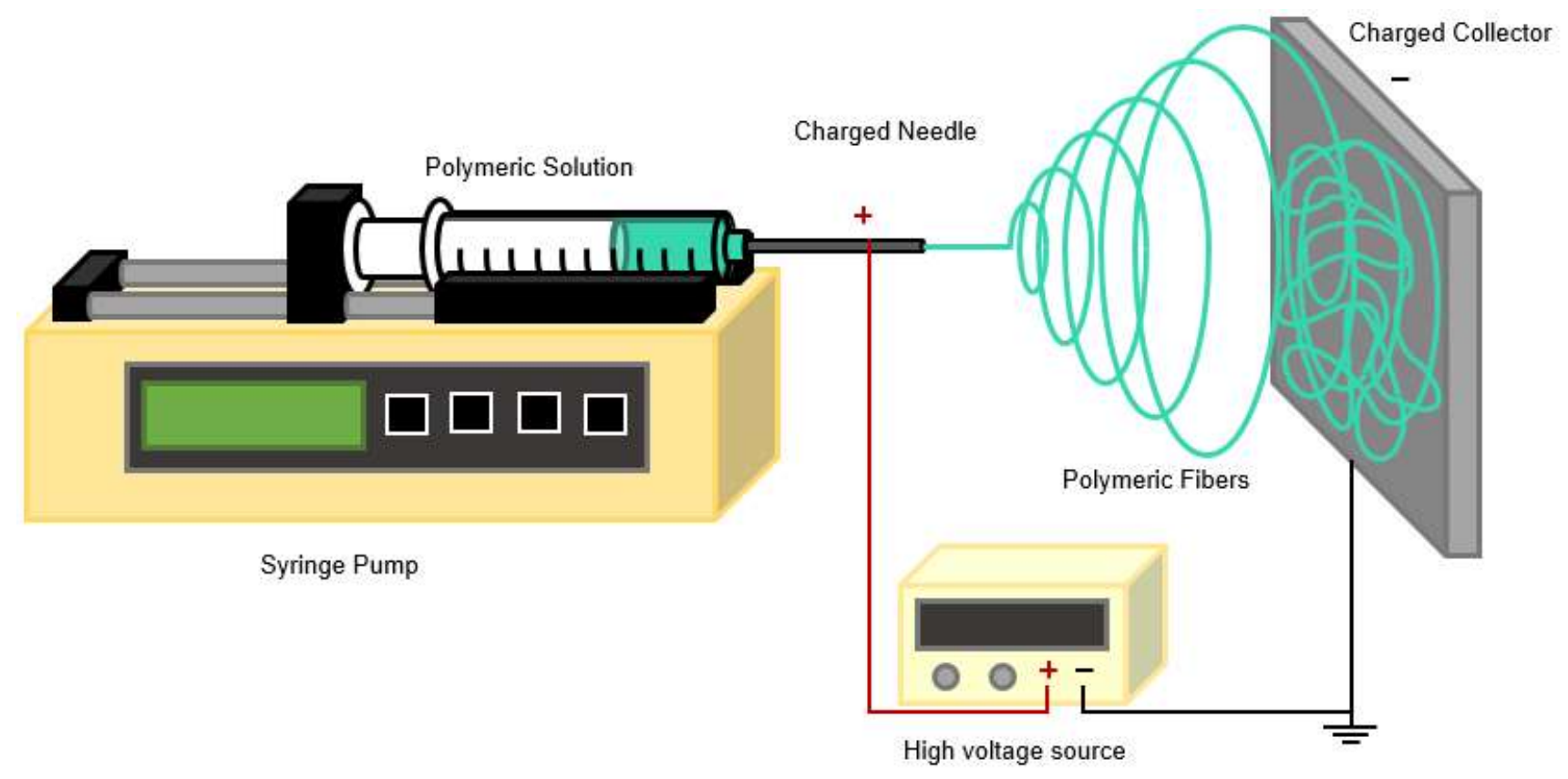

Figure 1. Basic diagram of the electrospinning device. 


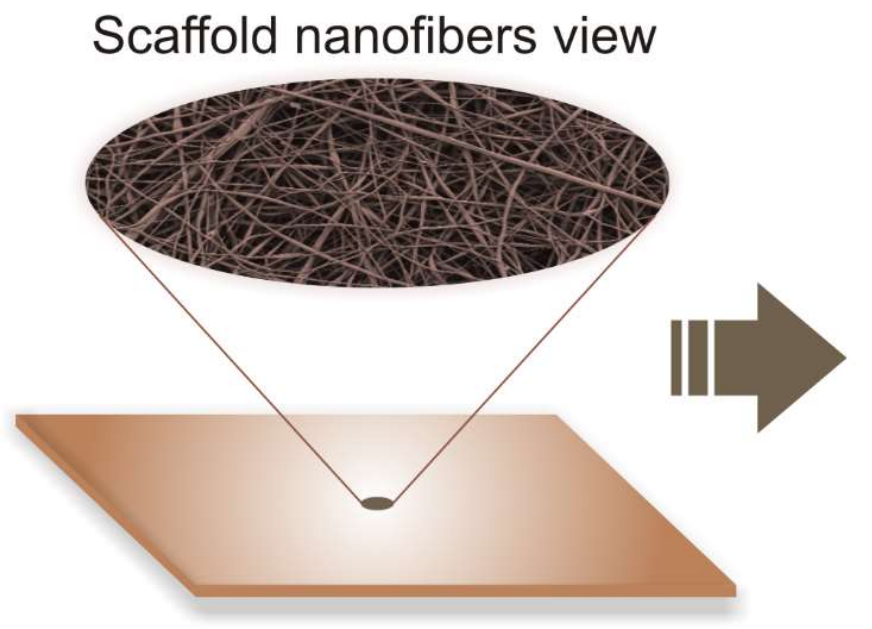

\section{Electrospun scaffold with selected drug}

Figure 2. Drug release from electrospun nanofibers.

\section{Polymers}

Today, many synthetic and natural polymers have been used as drug carrier materials in a form of micro or nanofibers fabricated by the electrospinning technique. These polymers, must be mainly biodegradable because the releasing of the drug is determined by the diffusion of the bioactive component and degradation of the polymeric fiber. This technique, allows to control the specific distribution of the drug around or inside the fibers leading the improvement of the release kinetics of the pharmaceutical components (9).

Biodegradable polymers, have attracted special attention in the pharmaceutics industry because avoid the necessity of a second surgery, which its function is to remove an implanted support. Between the polymers that have been extensively investigated as drug delivery systems are poly ( $\varepsilon$-caprolactone) (PCL), poly (vinyl alcohol) (PVAL), poly (vinyl pyrrolidone) (PVP), and chitosan (CHS), which have been successfully electrospun and its biomedical used have been proved (9).

The mechanism of release of the electrospun fibers is through its degradation; in other words, drug loaded fibers continuously release the biomedical components meanwhile the polymeric fibers go to its complete degradation. It is expected, that the polymer slowly breaks down into smaller, non-toxic fragments, releasing the drug wherever is necessary. This degradation is triggered by metabolic pathways that take effect for the natural elimination of these compounds (into simpler products) (8).
Moreover, the use of certain polymers or the modification of them, can improve the biocompatibility of a drug delivery system reducing body rejection. It has been reported, that using hydrophilic surfaces reduce tissue reaction (3). Between the reported hydrophilic polymers, it can be included alginate $(10,11)$, chitosan $(12)$, collagen $(13,14)$, dextran $(15,16)$ and hyaluronan $(17,18)$, these polymers resemble natural components of the body improving the disposal of its metabolites (3). Have been established, that several polymeric biomaterials provoke immune evasion through its surface properties, such as hydrophobicity, hydrophilicity, adhesive signal among others, the type of surface will determine the type of cellular response that occurs in the host. Some of the polymers that are able to evade immune system are poly (lactic acid), poly (lactic-co-glycolic acid) (PLGA), poly (ethylene glycol) (PEG) and poly (vinyl alcohol) (PVAL). Another strategy is the active modulation of the immune system through mimicking pathogen-associated molecular patterns (PAMPs), molecules that are detected by pattern recognition receptors (PRRs) located in both the membrane and cytosol of cells. An example, of polymers that do that are poly (ethylene glycol) (PEG) and poly (lactic-co-glycolic acid) (PLGA) (19).

In Table I, is listed natural and synthetic biocompatible polymers used as drug delivery system applications that have been electrospun. 


\begin{tabular}{|c|c|c|c|}
\hline Polymer & Properties & Loaded Pharmaceutical component & Ref. \\
\hline $\begin{array}{c}\text { Poly (vinyl } \\
\text { pyrrolidone) (PVP) }\end{array}$ & $\begin{array}{l}\text { Biocompatible, biodegradable, } \\
\text { increase dissolution of active } \\
\text { molecules, good hydrophilization } \\
\text { properties }\end{array}$ & $\begin{array}{l}\text { Ibuprofen, naproxen, indomethacin, } \\
\text { meloxicam, ketoprofen, acetaminophen, } \\
\text { feruloyl glycerol oleyl (FOG), loratadine, } \\
\text { spirolactone, griseofulvin, amocycilin, } \\
\text { sodium dodecylsulfate }\end{array}$ & $(20-31)$ \\
\hline $\begin{array}{l}\text { Poly (vinyl } \\
\text { alcohol) (PVAL) }\end{array}$ & $\begin{array}{l}\text { Non-toxic, non-carcinogenic, } \\
\text { bioadhesive, high degree of swelling } \\
\text { in water, rubbery, elastic nature } \\
\text { simulates natural tissue }\end{array}$ & $\begin{array}{l}\text { Sumatriptan, aceclofenac, caffeine, } \\
\text { riboflavin, docetaxel, ciproflozacin, } \\
\text { donepezil } \mathrm{HCl}\end{array}$ & $(7,31-34)$ \\
\hline $\begin{array}{l}\text { Poly (ethylene } \\
\text { oxide) (PEO) }\end{array}$ & $\begin{array}{l}\text { High binding efficiency, form novel } \\
\text { complexes, crosslink ability, } \\
\text { emollient, film former excipient, low } \\
\text { toxicity, flocculant activity, lubricity, } \\
\text { solubility/thickening of many organic } \\
\text { solvents, thermoplasticity, wet tack, } \\
\text { thickening power (aqueous), } \\
\text { viscoelasticity, nontoxic and } \\
\text { degradable }\end{array}$ & $\begin{array}{l}\text { Glycerol monolaurate, doxorrubicin, } \\
\text { paclitaxel }\end{array}$ & $(35-38)$ \\
\hline $\begin{array}{l}\text { Poly }(\varepsilon- \\
\text { caprolactone) } \\
\text { (PCL) }\end{array}$ & $\begin{array}{l}\text { Biocompatibility, higher } \\
\text { hydrolyzability, elastomeric } \\
\text { properties, high elongation, enhanced } \\
\text { solubility in organic solvents, ability } \\
\text { to be processed at low temperatures, } \\
\text { non-toxic degradation byproducts, } \\
\text { slow rate of degradation }\end{array}$ & $\begin{array}{l}\text { Ibuprofen, sumatriptan, naproxen, } \\
\text { carvedilol, tetracycline, amphotericin B }\end{array}$ & $(39-43)$ \\
\hline Chitosan & $\begin{array}{l}\text { Biodegradable, biocompatible, } \\
\text { mucoadhesive, oral absorption } \\
\text { enhancer }\end{array}$ & Sumatriptan & $(31,40)$ \\
\hline $\begin{array}{l}\text { Poly (acrylic } \\
\text { acid) (PAA) }\end{array}$ & $\begin{array}{l}\text { Biodegradable, good rheological } \\
\text { properties, exists as a liquid at } \mathrm{pH} 5 \\
\text { and as a gel at } \mathrm{pH} 7\end{array}$ & Sumatriptan & $(31,40)$ \\
\hline $\begin{array}{c}\text { Ethyl } \\
\text { cellulose (EC) }\end{array}$ & $\begin{array}{l}\text { Biocompatible, non-biodegradable, } \\
\text { retardant material }\end{array}$ & Ketoprofen & $(26,27)$ \\
\hline $\begin{array}{c}\text { Cellulose } \\
\text { acetate (CA) }\end{array}$ & $\begin{array}{l}\text { Cellulosic, thermoplastic, soluble in } \\
\text { many common solvents, hydrophilic, } \\
\text { high surface area }\end{array}$ & Ketoprofen & $(26,44)$ \\
\hline $\begin{array}{l}\text { Eudragit } \\
\text { S100 }\end{array}$ & $\begin{array}{l}\text { Soluble in gastric fluid, low toxicity } \\
\text { by the subcutaneous route }\end{array}$ & Aceclofenac & $(45,46)$ \\
\hline $\begin{array}{l}\text { Hydroxypropyl } \\
\text { methylcellulose }\end{array}$ & $\begin{array}{l}\text { Hydrophilic, } \\
\text { biocompatible }\end{array}$ & Diphenhydramine & $(47,48)$ \\
\hline $\begin{array}{l}\text { Poly L- (Lactic } \\
\text { acid) (PLLA) }\end{array}$ & $\begin{array}{l}\text { Biodegradable, } \\
\text { biologically inert }\end{array}$ & $\begin{array}{l}\text { Tetracycline hydrochloride, } \\
\text { doxorrubicin }\end{array}$ & $(37,49,50)$ \\
\hline
\end{tabular}




\begin{tabular}{|c|c|c|c|}
\hline $\begin{array}{l}\text { Poly (lactic-co- } \\
\text { glycolic acid) } \\
\text { (PLGA) }\end{array}$ & $\begin{array}{l}\text { Biodegradable, biocompatible, FDA } \\
\text { approved, modified surfaces provide } \\
\text { better interaction with biological } \\
\text { materials, suitability for export to } \\
\text { countries }\end{array}$ & $\begin{array}{l}\text { Metoclopramide hydrochloride } \\
\text { paclitaxel }\end{array}$ & $(41,49,51)$ \\
\hline $\begin{array}{l}\text { Poly (acrylonitrile) } \\
\text { (PAN) }\end{array}$ & $\begin{array}{l}\text { Low density, thermal stability, high } \\
\text { strength and modulus of elasticity, } \\
\text { stability to UV degradation, } \\
\text { nonfusible, chemical resistance }\end{array}$ & Acyclovir & $(52,53)$ \\
\hline $\begin{array}{l}\text { Poly (urethane) } \\
\text { (PU) }\end{array}$ & $\begin{array}{l}\text { Good biocompatibility, flexural } \\
\text { endurance, high strength, high } \\
\text { abrasion resistance, processing } \\
\text { versatility }\end{array}$ & Itraconazole & $(54-56)$ \\
\hline $\begin{array}{c}\text { Cellulose acetate } \\
\text { phthalate }\end{array}$ & $\begin{array}{l}\text { Enteric coating, hygroscopic, } \\
\text { biocompatible, anti-microbicidal }\end{array}$ & Tenofovir, disoproxil fumarate & $(57,58)$ \\
\hline
\end{tabular}

\section{Electrospun nanofibers as drug delivery systems} Electrospun fibers, possess several characteristics that are useful in pharmaceutics, such as a large surface area, a possibility of loading large amounts of drug, simultaneous administration in various therapies, ease of operation, and cost-effectiveness have led to its use being expanded in the area of drug administration. These properties make them good candidates for the administration of poorly watersoluble or low-bioavailability drugs. Among the most investigated areas, drug delivery (either rapid dissolution or controlled release), tissue regeneration and local cancer treatments are of the most interest $(59,60)$. The following are some of the drugs used in the electrospinning area.

\section{Anti-inflammatory}

The anti-inflammatory drugs are substances that its main function is to reduce inflammation and swelling, they possess an analgesic and antipyretic activities (61). These kinds of drugs have been extensively loaded into nanofibers using the electrospinning method, because many of them are poorly water soluble, which become an issue for the patient that desired an immediate effect using the conventional pharmaceutical formulations. As shown below, with the electrospinning technique, the electrospun nanofibers are usually developed with an anti-inflammatory and with another pharmaceutical component to have an improved treatment.

One of the most studied drug is ibuprofen, which is a therapeutic agent in the class of nonsteroidal used to treat pain, fever and inflammation. This includes painful menstrual periods, migraines and rheumatoid arthritis (62). Ibuprofen has been loaded into polymeric nanofibers such as PVP K30 $(20,45)$ and PCL (40), using the electrospinning technique because of its properties, such as poorly water soluble and high bioavailability (20).

Another drug that has been incorporated in the fibers is naproxen, which is a non-steroidal antiinflammatory drug that relieves pain, fever, swelling and stiffness (62). Naproxen was incorporated into electrospun sheets through the electrospinning process. Electrophilic anti-inflammatory drugs have been studied in combination with other drugs for a more effective treatment. In this case naproxen was combined with sumatriptan succinate. They were studied alone and in combination. The release of naproxen and sumatriptan with three hydrophilic polymers was tested: CHS, PVAL and poly (acrylic acid) (PAA); and one hydrophobic: PCL. All polymers provided a release of more than $90 \%$ of the releasable drug and it was dissolved in the acceptor phase within $10 \mathrm{~min}$. Interestingly, the membranes that showed fast release of the two drugs was made of hydrophobic PCL. SEM micrographs showed that the nanofibers had the desired homogeneity. Moreover, the resulted membranes turned out to be very flexible and mechanically resistant. With their drug loading capacity of up to $40 \%$ membrane mass, which could be very advantageous for the formulation of sublingual drug delivery systems (41).

In another research, coaxial electrospinning was successfully performed to make naproxen-loaded PVP nanofibers. Field emission scanning electron 
microscopy (FESEM) showed that higher quality nanofibers could be produce, with a diameter of 270 $\pm 60 \mathrm{~nm}$, also with linear morphologies, with no beads or spindles and a smooth surface. The XRD patterns verified that the nanofibers were amorphous nanocomposites with the drug distributed homogeneously in the polymer. In vitro dissolution tests showed that the medicated nanofibers could release the contained drug all at once while in contact with the dissolution medium, which is considerable faster than the commercially dispersible tablets (42).

PCL was selected as the polymer matrix to create a drug delivery system for naproxen. This drug was complexed with beta-cyclodextrin (BCD) to form an inclusion complex and then electrospun. SEM images showed that the fiber diameter was around $300 \mathrm{~nm}$. The complex drug in the fibers showed a better release than the fibers with uncomplexed drug, this was possible because the complex improved the solubility of the drug (42).

Also, indomethacin, which is a non-steroidal anti-inflammatory drug is estimated to be 20 times more potent than acetyl salicylic acid (62). Several experiments were realized for the optimization of a release system, involving two sets of electrospun PVP fibers loaded with indomethacin, using an acetone/dimethylacetamide solvent system. It was possible to obtain loadings up to $33 \% \mathrm{w} / \mathrm{w}$. SEM images showed that the fibers were smooth and uniform. It was also found by XRD and DSC that the drug exists in amorphous physical state in the fibers.

The amorphous form of the drug was found to be stable after storage of the fibers for 8 months in a desiccator (relative humidity $<25 \%$ ). Finally, the functional performance of the fibers was studied. In all cases, drug-loaded fibers released their components quickly, offering accelerated dissolution over the pure drug (22).

Meloxicam has also been electrospuned into nanofibers for immediate release. This formulation is from oxycodone derivatives, which are enolic acids that inhibit COX-1 and COX-2 with antiinflammatory, analgesic, and antipyretic activities. Meloxicam has a similar efficacy to aspirin, indomethacin and naproxen, for the long-term treatment of rheumatoid arthritis or osteoarthritis (60). Despite this, poor absorption of the drug occurs after oral administration because of its low solubility. Samprasit, W, et al. (2015), PVP fibers were loaded with meloxicam. The creation of PVP fibers and the incorporation of $\mathrm{BCD}$ and sweeteners were carried out to improve the solubility, disintegration time and release, as well as the taste of the dosage forms. The created drug delivery system of meloxicam shown to be viable for drug release (23).

Ketoprofen is another non-steroidal antiinflammatory drug that it is derived from propionic acid and has analgesic and antipyretic effects. In addition to the inhibition of the COX, it can stabilize the lysosomal membranes and antagonize the actions of bradykinin. PVAL nanofibers containing ketoprofen have been developed as a drug delivery system. Researchers were successfully to prepare PVAL fibers stabilized against the disintegration in water by treatment with methanol. Fibers were analyzed by UV spectrophotometer at body temperature $\left(37{ }^{\circ} \mathrm{C}\right)$, and at room temperature $\left(20^{\circ} \mathrm{C}\right)$. The results showed that fibers treated with methanol do not present accelerated release, but a controlled release fashion. This may be beneficial for certain treatments that need more controlled release (33).

In another research, the production of electrospun ethyl cellulose (EC), cellulose acetate (CA) and PVP nanofibers loaded with ketoprofen were presented, in conjunction with their in vitro drug release profiles. SEM images showed clear formation of duplicate nanofibers that appear to be affected by the solvent and amount of drug used. The in vitro drug release studies showed that nanofibers having hydrophilic polymer had a high drug loading percentages but shows faster drug release compared to those hydrophobic polymeric nanofibers, which presented lower drug loading percentages (24).

On the other hand, acetaminophen is used for the relief of a mild to moderate pain because acetaminophen increases the threshold to painful stimuli and therefore exerts an analgesic effect against pain due to various causes (62). Acetaminophen it's another low water-soluble drug that has also been electrospun. Yu, D.-G. et al. (2010), prepared solid dispersions of acetaminophen to produce PVP loaded nanofibers. Solid dispersions of electrospun fibers were compared to those prepared from three traditional dispersion system processes: By freeze drying, vacuum drying and heating drying. Using SEM, DSC, XRD, and FTIR techniques, the surface morphologies, drug physical status, and drug-polymer interactions were investigated, as well as an in vitro dissolution. The tests demonstrated that electrospun nanofibers released $93.8 \%$ of the acetaminophen content within 
the first $2 \mathrm{~min}$ and that the acetaminophen dissolution rates of the different solid dispersions and solid dispersions that were electrospun into nanofibers showed better dissolution effects in comparison to the other solid dispersions due to their large surface area, high porosity and homogeneous distribution of acetaminophen in the fibers (25).

Feruloyl glycerol oleyl (FOG) is poorly soluble in water due to the long chain of the acyl group, which may limit its use, even with its excellent properties. FOG has also been successfully eluted for the creation of fast dissolving drug release membranes PVP, as base polymer matrix, these being dissolved in chloroform/ethanol. The FTIR spectra revealed a good compatibility between FOG and PVP, as well as a good FOG distribution within the fibers. It was observed that the diameter of the fibers was influenced by the concentration of PVP and voltage. In this case, fibers with a diameter of 700-800 $\mathrm{nm}$ were obtained. The release assays confirmed that the fibers were indeed of rapid dissolution with mean dissolution time of $2.0 \pm 1.5 \mathrm{~s}$. These results demonstrated the potential of solid dispersion electroplating to improve the dissolution profile of hydrophobic drugs (64).

In a study, diclofenac sodium (sparingly soluble in water), naproxen and indomethacin (both water insoluble) were electrospun with PVA as the drug carrier. These drugs were non-steroidal antiinflammatories with different water solubility's. The morphological appearance of the drug-loaded fibers depended on the compositions of the drugs. The study proposed that the chemical composition of the drugs was not affected by the electrospinning process, these conclusions were supported with a ${ }^{1} \mathrm{H}$ NMR spectra analysis. DSC and TGA analyzed the thermal properties of the fibers mats. Also, the molecular weight of the drugs used in their research played an important role on the rate and the total amount of the drugs release, both decreasing when the increase of the molecular weight of the drugs. They also compared the release characteristics of drug loaded fibers and films, and conclude that the fibers exhibited much better release characteristics of the model drugs than the drug-loaded film (65).

Finally, aceclofenac was electrospun with pantoprazole. This combination has the purpose of restricting and compensating adverse effects of nonsteroidal anti-inflammatory drugs, so the coadministration of proton pump inhibitors may be beneficial to arthritis patients. These drugs were simultaneously electrospun by using a composite solution of zein/Eudragit S100. The physical-thermal characterization of the nanofibers showed the drugs with the polymers had a molecular integration, and so the drugs were evenly distributed in the nanofibers in the amorphous state. In vitro release studies maintained the release of both drugs until $8 \mathrm{~h}$, making it a good candidate for a controlled release treatment. Co-administration of pantoprazole together with aceclofenac reduced gastrointestinal toxicity induced by non-steroidal anti-inflammatory drugs; this was confirmed by animal experiments in vivo. The researchers successfully developed a dual drug delivery system comprising polymers with different release characteristics and achieved oral administration of aceclofenac with reduced side effects (45).

\section{Antihistamine drugs}

An antihistamine is a type of pharmaceutical drug that opposes the activity of histamine receptors in the body. These are subclassified according to the histamine receptor. The two largest classes of antihistamines are $\mathrm{H} 1$ antihistamines and $\mathrm{H} 2$ antihistamines. This study focused on H1s, which target the histamine $\mathrm{H} 1$ receptor and are used to treat allergic reactions in the nose (e.g., itching, runny nose and sneezing), as well as for insomnia. They are also sometimes used to treat dizziness or vertigo caused by problems with the inner ear.

Loratadine is useful to relief symptoms of allergies, such as fever, urticaria, chronic idiopathic, urticaria, and other skin allergies. For allergic rhinitis, loratadine is effective for both nasal and ocular symptoms: sneezing, runny nose, itching or burning eyes (42). This drug has also been successfully electrospun in PVP nanofibers. A study observed that using a low polymer concentration, low feed rate in the injection pump, and high applied voltage nanofibers with a smaller diameter and greater uniformity were created. The study concluded that the smaller the diameter of the fiber and the amount of drug, the faster its dissolution, and the time of release of this pharmaceutical component (26).

Another antihistamine is diphenhydramine, which decreases or prevents the histamine effects on smooth muscle and immune cells, as well as antagonizes muscarinic receptors and $\alpha$-adrenergic receptors. This drug is normally used for insomnia, common cold symptoms and nausea $(66,67)$. Diphenhydramine has been electrospun directly onto 
a polymeric film of hydroxy propyl methyl cellulose (HPMC), and glycerol to improve the mucoadhesive system. Their effects on the measured responses: disintegration time, adhesion work, adhesion strength, the area under the curve (at $1 \mathrm{~min}$ ), and the area under the curve of the permeation (at $3 \mathrm{~min}$ ) were used to calculate the dependent variables of the process: the filling volume, HPMC and the glycerol concentration. The physicochemical and physicomechanical properties of the developed system were studied with the following methods: rheology, FTIR, determination of tenacity, mucoadhesion and nanotensile tests. The data obtained from the physical-mechanical characterization confirmed the suitability of the systems for the application in the delivery of drugs. The optimized system showed drug entrapment of $2.3 \mathrm{mg} / 1.5 \mathrm{~cm}^{2}$ with disintegration time of $12.8 \mathrm{~s}$ (47).

\section{Drugs for the treatment of gastrointestinal diseases}

Not many studies have been done, using the electrospun scaffolds as drug delivery system of gastrointestinal drugs. Metoclopramide is one of the oldest real prokinetic drugs. Its administration results in coordinated contractions that intensify the intentional transit. Its effects are largely confined to the upper portion of the digestive tract, where it increases the tone of the lower esophageal sphincter and stimulates antral and small intestinal contractions. Although it has in vitro effects on contractility of smooth muscle colonic, metoclopramide has no clinically important effects on the motility of the large intestine (68).

Liu, H., et al. (2007), suggest a possible approach to the controlled release of metoclopramide hydrochloride using core-shell electrospinning. Using various polymers (PCL, PLLA and PLGA $80 / 20$ ). The strategies were proposed for the control of the distribution of the release. The fibers consisted of two layers, the polymer on the outside and the drug inside. By varying the physical and chemical properties of the core and shell solutions, it was shown that the rate of release of this hydrophilic drug was controllable. The study discusses the importance of controlled release of hydrophilic molecules, such as peptides, proteins and even pDNAs (plasmid DNA), and their difficulty in being administered. The results showed a clear difference in the release pattern between monolithic fibers made from hydrophilic and hydrophobic polymers and various core-shell fibers with PCL, PLLA and PLGA 80/20 as shell polymers (44).

\section{Drugs for the treatment of cardiovascular diseases (CVD)}

Nicorandil is a vasodilator therapeutic agent that can hyperpolarize muscle tissues, and is an effective coronary vasodilator. It seems to be active in all types of angina pectoris, including advanced coronary artery lesion (70). Polymeric fibers were electrospun for the sublingual administration of nicorandil in an attempt to reduce mucosal ulceration and improve bioavailability of the drug. Polymeric nanofibers were obtained using vitamin B12, and a mixture of hyaluronic acid and PVAL. The morphology, drug loading, XRD, DSC, in vitro drug release, degree of swelling and their pharmacokinetic behavior of the resulting fibers were characterized. Nanofibers were found to be homogeneous with a diameter of 200-450 nm. Histopathological studies showed no evidence of mucosal ulceration at the site of application. Preclinical safety was checked and maintenance of an effective therapeutic level over an extended period was demonstrated. The study showed that the biocompatible nanofiber become a perfect carrier system for the sublingual administration of antianginal drugs (71).

Moreover, PVP K90 nanofibers loaded with a lipophilic spironolactone were prepared, which is a drug that is mainly used to treat fluid accumulation due to heart failure, liver scarring, or kidney disease, and for the treatment of high blood pressure. However, temporary precipitation was observed. Vigh, T. et al. (2013), used beta-cyclodextrin to improve the immediate release of the drug. A small addition of beta-cyclodextrin provided sufficient for a dramatic increase in the rate of release, even at high concentrations of drug. This approach ensured the near-total release of the drug in one minute, making the system a suitable formulation for rapid release (28).

Potrč, T. et al. (2015), studied the cardiovascular drug carvedilol, which is a drug that is indicated in the treatment of congestive heart failure. It is indicated in the treatment of hypertension and to reduce the risk of mortality and hospitalizations in a subset of people after a heart attack. It may be used alone or with other antihypertensive agents. It was observed that the incorporation of this drug into PCL 
electrolyzed fibers reduced its crystallinity. By DSC studies, the study demonstrated that the incorporated drug in the nanofibers were partially molecularly dispersed in the polymer matrix, and partly in the form of dispersed nanocrystals. The incorporation of the drug into PCL nanofibers significantly improved their dissolution rate. PCL nanofibers released nearly $77 \%$ of the incorporated carvedilol in $4 \mathrm{~h}$, indicating the influence of drug properties, such as molecular weight and solubility, on their release from the polymer matrix (40).

\section{Contraceptives}

In the case of contraceptive drug, not many studies have been done, due of the difficulty of the in vivo or application studies. Contraceptives drugs are applied to prevent pregnancy. Estrogen and progestin are two female sex hormones that in combinations avoid ovulation. These hormones also modify the lining of the uterus (womb) to prevent the development of pregnancy, and modify the mucosa of the cervix to prevent sperm from entering (62).

In a study, electrospun PVAL nanofibers were loaded with progestin levonorgestrel, the system was stacked on tissue paper and studied the release kinetics of the drug and measured its cytotoxicity. It was observed that the in vitro release of levonorgestrel was affected by the composite microarchitecture, thickness and drug content, whereby the electrospinning process was optimized (73).

\section{Anticancer}

Docetaxel is a well-known mitotic inhibitor for oral cancer. It faces problems of extravasation, inflammation of the veins, and other side effects of chemotherapy (7). Singh, H. et al. (2015), design a mucoadhesive nano-carrier system that is maintained at the site of application and maximizes the therapeutic potential of the anticancer drug, as well as attenuate its systemic side effects. In the study, PVAL/docetaxel fibers were prepared using the electrospinning method. The resulting fibers were characterized by surface morphology, drug loading, in vitro drug release, tensile strength, mucoadhesivity, drug permeability, degree of swelling, and anticancer activities against selective cell lines, to establish their therapeutic potential, demonstrating polymeric nanofibers can be successfully used for local administration of anticancer drugs $(7,70)$.
An electrospun system of five layers was developed, using cisplatin and PLA nanofibers. The first, third and fifth layer are made from polymer and the second and fourth layer, drug was incorporated. This for a prolonged release of cisplatin to prevent local cancer recurrence after a surgery. Cisplatin is used in the treatment of cancer, mostly liver cancer, but one of the main issues of this drug is that tends to accumulate on the liver and has a poor intake after intravenous administration. The in vivo studies of 24 $\mathrm{h}$ showed that the multilayer fiber mat had a prolonged release and the retention in the tissue was more stable. The authors observed, in the studies with mice, that liver cancer had been retarded; mice had a prolonged survival time, and there was a reduced toxicity, compared with other groups with different treatments (73).

Also, doxorubicin is a chemotherapy medication used in some numerous types of cancer. This includes leukemia, lymphoma and many types of carcinoma (solid tumors), and soft tissue sarcomas. It is usually given by injection into a vein. The electrospinning of fibers loaded with doxorubicin has been extensively studied. In one report, the authors developed fibers using a water-in-oil emulsion. The polymers used were poly (ethylene glycol) and poly (L-lactic acid) (PEG-PLLA), these were dissolved in chloroform which constitute de oily phase. Doxorubicin was contained in the aqueous phase, with the purpose of encapsulate the drug in the fibers. The diameter of the electrospun fibers was in the range of $300 \mathrm{~nm}-1 \mu \mathrm{m}$. The content of doxorubicin in the fibers was $1-5 \%$ by weight, and it was fully encapsulated within the fibers. Release was controlled by the combined diffusion and enzymatic degradation mechanism. In the initial stage, the diffusion mechanism was predominant and sometime later, the mechanism of enzymatic degradation became predominant. The antitumor activity of doxorubicin incorporated into PEG-PLLA fibers versus mouse glioma cells (C6 cell lines) was assessed by the MTT method. The results showed that doxorubicin could be released from the fibers without losing cytotoxicity (37).

$\mathrm{Xu}, \mathrm{X}$. et al. (2009), studied the drug release behavior of drug-loaded nanofibers prepared by an emulsion method. Confocal microscopy images indicated that the drug was incorporated in the PEGPLLA copolymer nanofibers, forming drug-loaded structural fibers. Drug release behavior of this system showed a three-stage diffusion controlled 
mechanism, in which the rate of release of the first stage was slower than the second stage, but both followed the second law of Fick. Hence, it was concluded that the rate of doxorubicin release decreases when is present a higher concentration of fibers (38).

Salehi, R. et al. (2013), fabricated stimuli sensitive poly (N-isopropylacrylamide-coacrylamide-co-vinyl pyrrolidone) (P(NIPAAMAAm-VP)) nanofibers loaded with doxorubicin. The prepared systems were characterized by XRD, SEM and FTIR. The cytotoxicity of the samples was evaluated by MTT test using a A549 lung cancer cell line. The in vitro cytotoxicity assay showed that P(NIPAAM-AAm-VP) fibers did not affect the growth of A549 cells. The antitumor activity of DOX-loaded fibers against cells was maintained, whereas DOX disappeared within $48 \mathrm{~h}$ (74).

In the case of paclitaxel, which is a drug that acts as a toxic substance for the mitotic spindle through its binding of high affinity to the microtubules with the intensification of tubulin polymerization (75). A study was performed incorporating a system of two drug: doxorubicin and paclitaxel. These drugs were successfully loaded onto the PEG-PLLA fibers. The release behaviors of both drugs from the same fiber mats were attributed to their solubility and distribution status in the fibers. Due to its high hydrophilicity, doxorubicin was easy to diffuse from the fibers, and its release rate was always faster than that of the hydrophobic paclitaxel. In addition, the rate of release of paclitaxel was accelerated by the release of doxorubicin. In vitro cytotoxicity against rat C6 glioma cells indicated that the dual drug combination showed greater inhibition and apoptosis compared to single-drug system, suggesting the promise of multiple drug delivery in therapy that combines pharmaceutical components $(38,76)$.

\section{Antimicrobials}

Lopez, F. L. et al. (2014), prepared PVP/griseofulvin electrospun fibers, with the purpose of treat mycotic diseases of the skin, hair and nails due to Microsporum, Trichophyton or Epidermophyton infections. SEM images showed that the fibers comprised to a large extent in being smooth and uniform. It was also found that the drug existed in amorphous physical state in the fibers with the XRD technique and DSC. The amorphous form of the drug was found to be stable after storage of the fibers for 8 months in a desiccator (relative humidity $<25 \%$ ).
Finally, the functional performance of the fibers was studied. In all cases, drug-loaded fibers released their components fast, offering accelerated dissolution over the pristine drug (22).

The permeability of the electrospun PVAL fibers with ciprofloxacin has been studied, this drug inhibits DNA replication by binding to DNA gyrase and topoisomerase IV. The research focused on examining the permeability of ciprofloxacin from PVAL nanofibers through different biological membranes. The researchers indicated that the fibers had greater drug permeability than the drug alone. These studies also reported that there was a steadystate release of the drug, which has not been seen with the current presentations of the drug (which has a high degree of fluctuations). As a conclusion, fibers provide numerous advantages for its use as a support system for encapsulating drugs and thus enhancing current therapies $(75,77)$.

Ball, C. et al. (2012), evaluated the viability to release the glycerol monolaurate (GML) drug, which has been proposed as a microbicide component by blocking transmission-facilitating innate immune response to vaginal exposure. The purpose of the study was to create a multipurpose prevention technologies that simultaneously prevent sexually transmitted infections (STIs), and prevents unwanted pregnancy. It was demonstrated that GML scaffolds designed for topical administration can function as a combination of chemical and physical barrier for a prevention technology. The authors used FDAapproved polymers (PLLA-PEO) to prepared controlled-release fibers that facilitate the simultaneous release of multiple agents against HIV1, HSV-2 and sperm. In this work, it was observed that drug-loaded fibers inhibited HIV-1 infection in vitro and physically obstructed the penetration of spermatozoa. In addition, previously unknown activity of GML is reported to potently inhibit the motility and viability of spermatozoa. Application of nanofibers eluting drugs for HIV-1 prevention and sperm inhibition can serve as an innovative platform for drug delivery in the lower female reproductive tract (36).

Also, tetracycline, chlorotetracycline hydrochloride and amphotericin B were loaded into PCL-PLA nanofibers. Their release properties and antimicrobial efficacies were studied. By forming PCL-PLA fibers, the surface and release characteristics could be modified to conform to a sensitive drug delivery. With the obtained results of 
this work, electrospun system can be adapted to the physiological conditions of the human body, and how they have become increasingly important for clinical applications in recent years. Electrospun fibers offer special advantages because of their large surface area and their sorption/release properties. If loaded with drugs, the administration properties can be adapted to a specific release rate (50).

He, C. et al. (2006), fabricate core-shell PLLA/ tetracycline hydrochloride (TCH) fibers for drug delivery application, using a coaxial electrospinning method. The results indicated that a reservoir-type drug delivery device can be conveniently obtained by the encapsulation of tetracycline hydrochloride in the PLLA fiber. A sustained release of TCH from these nanofibers was observed in the research, so drugcontaining hydrophilic fibers can be used as drug delivery vehicles or transformed into biomedical devices such as sutures and wound dressings (78).

Other fibers, that have been investigated are the cellulose acetate/PVP-amoxycillin/cellulose acetate fibers. In these fibrous complexes, mechanical characterization of the fibers showed that the tensile strength of the membrane is not affected by the presence of amoxicillin inside the fiber. The amount of amoxicillin release increased with increasing $\mathrm{pH}$, from $61 \%$ for a $\mathrm{pH} 3$ to $79 \%$ at $\mathrm{pH} 7.2$. It was proposed that amoxicillin release is due to a diffusion mechanism. These composites are recommended to resolve the problem of possible drug loss during the matrix entrapment process with potential local application in biological media to treat dental or cutaneous infections (29).

On the other hand, HIV still affects the health of millions of people around the world and a lot of effort is being put into developing methods to prevent infection or eradicate the virus after infection. The use of cellulose acetate phthalate (CAP) electrospun fibers with tenofovir disoproxil fumarate as a tool to prevent transmission of HIV have been proposed. Interestingly, because of the $\mathrm{pH}$ dependent solubility of the CAP, the fibers are stable in the vaginal fluid (healthy vaginal flora has a $\mathrm{pH}$ below 4.5), while the addition of small amounts of human semen (pH between 7.4 and 8.4) immediately dissolves the fibers that give rise to the release of the encapsulated drugs. The $\mathrm{pH}$-dependent release properties have been carefully studied and it is shown that the antiviral drugs released along with $\mathrm{CAP}$, which have been reported to have intrinsic antimicrobial activity, efficiently neutralize HIV in vitro (55).

In another study, acyclovir was selected as a model drug, PVP as a hydrophilic filament-forming polymeric matrix, sodium dodecyl sulfate as a transmembrane enhancer and sucralose as a sweetener. The study, successfully prepared the core-shell nanofibers, with the shell part consisting of PVP, sodium dodecyl sulfate and sucralose, and the core part composed of PVP and acyclovir. In the results, the authors reported that the core-shell nanofibers had an average diameter of $410 \pm 94 \mathrm{~nm}$ with a uniform structure and a smooth surface. Trough DSC and XRD was determined that acyclovir, sodium dodecylsulfate and sucralose was well distributed in the amorphous matrix of the PVP. In vitro dissolution and permeation studies demonstrated that solid dispersions of core-shell nanofibers could rapidly release acyclovir in one minute, with an increased permeation rate six-fold across the sublingual mucosa compared to that of the crude acyclovir (30).

In a comparative research, three methods were tested to produce a copovidone/itraconazole drug delivery system, using casting films, spray-drying, electrospinning, and high-speed electrospinning. The formulations were evaluated in terms of improvement in the dissolution rate of itraconazole and were analyzed by SEM, DSC and XRPD. Despite the significant increase in productivity of high speed electrospinning, the morphology obtained was very similar to the fibrous material of simple electrospinning. The results of the DSC and XRPD showed that the drug was transformed into an amorphous form in most cases, except for the film casting samples. The limited solution of crystalline itraconazole could be highly improved: rapid dissolution ( $>90 \%$ in $10 \mathrm{~min}$ ) occurred in the case of both high-speed and single-needle electrospun fiber types. This work proved, that using the high-speed electrospinning system to produce fibers with the amorphous solid dispersions it's a good alternative for the single-needle electrospinning, this because the fibers were flexible, the process was scalable, and easy to be set in a continuous manufacturing line (54).

Finally, itraconazole and ketanserin were loaded into poly (urethane) (PU) fibers. It was obtained an amorphous nanodispersion for ketanserin with dimethylformamide (DMF), and ketanserin with dimethylacetamide (DMAc). It was demonstrated that the collected fibers release the drugs at various 
speeds and profiles based on the morphology of the nanofibers, and the content of the drugs. The data were generated using a specially designed release apparatus around a rotating cylinder. The authors found that loading a small amount of itraconazole, the fibers released as a linear function of the square root of time, Fick kinetics, and that the drug did not have an initial burst release (57).

\section{Drugs used in palliative medicine}

In this area, not many studies have been done, despite this, a nanofibers loaded with donepezil $\mathrm{HCl}$ were prepared as a dosage form so that it was dissolved orally. This research aimed to create a removable scaffold using an ultrafast release electrospinning device, using PVAL as the matrix polymer, and donepezil. $\mathrm{HCl}$ as the drug to be loaded. Kadajji, V.G. et al. (2011), found diameters between $100 \mathrm{~nm}$ and $300 \mathrm{~nm}$ in their resulting nanofibers. The in vitro tests showed that it had an immediate release, less than $30 \mathrm{~s}$, regardless of the drug content in the fibers, this is because of the large surface area the nanofibers. The study, compared the scaffolds and the commercial tablets and conclude that the electrospinning technology was a promising method to produce alternative effective dosage forms, especially with patients, children, and elderly people with dysphagia (32).

\section{Miscellaneous}

Caffeine temporarily prevents or alleviates drowsiness, and therefore maintains or restores alertness. Between the uses of caffeine as a pharmaceutical drug it can be include in bronchopulmonary dysplasia in preterm infants, for both prevention and treatment, apnea of prematurity as primary treatment, treatment of orthostatic hypotension and general vasodilation. Usually used for vasodilation to relieve headaches, or even migraine. In contrast, riboflavin (vitamin B2) is used in individuals with protein depletion and infections that complicate it.

Li, X. et al. (2013), prepared PVAL electrospun nanofibers loaded with caffeine and riboflavin. SEM images showed that nanofibers had an ultrafine morphology with an average diameter in the range of 260-370 nm. Also, PVAL/caffeine and PVAL/riboflavin nanofibers had almost the same dissolution time (approximately $1.5 \mathrm{~s}$ ), and wetting time (approximately $4.5 \mathrm{~s}$ ). Both drugs can be released in an accelerated manner (caffeine in an extent of $100 \%$, and riboflavin up to $40 \%$ in $60 \mathrm{~s}$ ) (34).

In the case of preclinical studies, have mainly focused on formulation methods to enhance the dissolution of active compounds, in many cases without considering that the formulation matrix affects not only dissolution but also influences the transport of the molecules of the drug through membranes. It has been reported a study that test an electrophilic formulation based on cyclodextrin of aripiprazole, with an apparatus ( $\mu$ Flux) which monitors the permeation along with the dissolution, and by this means a better in vitro-in vivo correlation. It has been demonstrated that an electrospinning formulation based on cyclodextrin-aripiprazole has the potential to ensure rapid delivery of drug through the oral mucosa due to the rapid dissolution of the drug in the formulation and the improved flow through the membranes, as shows by the result of the new in vitro dissolution and permeation test (79).

\section{In vivo studies in animal models}

In the case of in vivo application of drug loaded electrospun nanofibers, the literature has reported only animal models, most frequently rodents. Depending on the drug, the animal model is prepared for the experiments, but just after the samples showed good results in in vitro test, and a bioethical committee have approved the assays. Because of the nature and morphology of the fibers, in vivo tests are usually implanted subcutaneously and intramuscularly at the back of the rodent, depending of the study fibers are left hours or days respectively (Figure 3).

Until now, not many literature can be found about the in vivo application of drug loaded electrospun nanofibers, but between the most studied pharmaceutical applications it can be found antiinflammatory, gastrointestinal, anti-cancer and antimicrobial activities (91-84) (Table 2), and no in vivo studies have been performed on anti-histamine, contraceptive, palliative and miscellaneous drugs, these can be due to the difficulty of the study.

\section{In vivo studies in human volunteers}

Electrospun nanofibers meant to be used as drug delivery systems have been documented extensively with clear advantages over bulk materials thanks to their large specific surface and short diffusion path length. However, in order to take these scaffolds to the market, they have to pass through in vivo studies 
before clinical applications. Most of the reported systems requires further investigation, and extensive experimental campaigns are needed before making products fully ready for commercialization (85). Some examples electrospun systems that have gone through studies using human volunteers are listed in Table 3 .

\section{CONCLUSION}

The electrospinning method have gaining importance in the pharmaceutical industry, as an alternative strategy to developed a new form to administrate and transport pharmaceutical drugs. Nano or microfibers produced by this technique possess such some interesting advantages over the other methods of administration. Its intrinsic high surface-volume ratio, its versatility of fibers composition, its surface bioactivity, the manipulation of the drug release rate, its easy fabrication and cost-effectiveness operation are all attractive features for its drug delivery application.

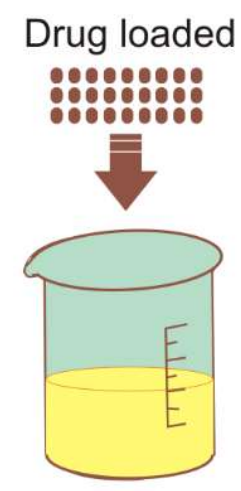

Polymeric solution

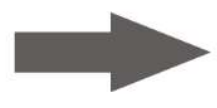

In vivo studies

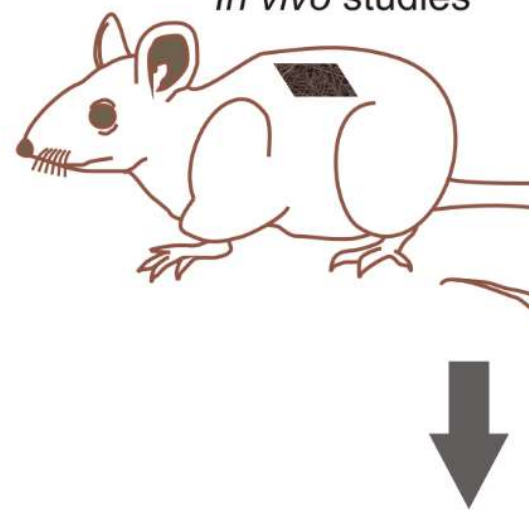

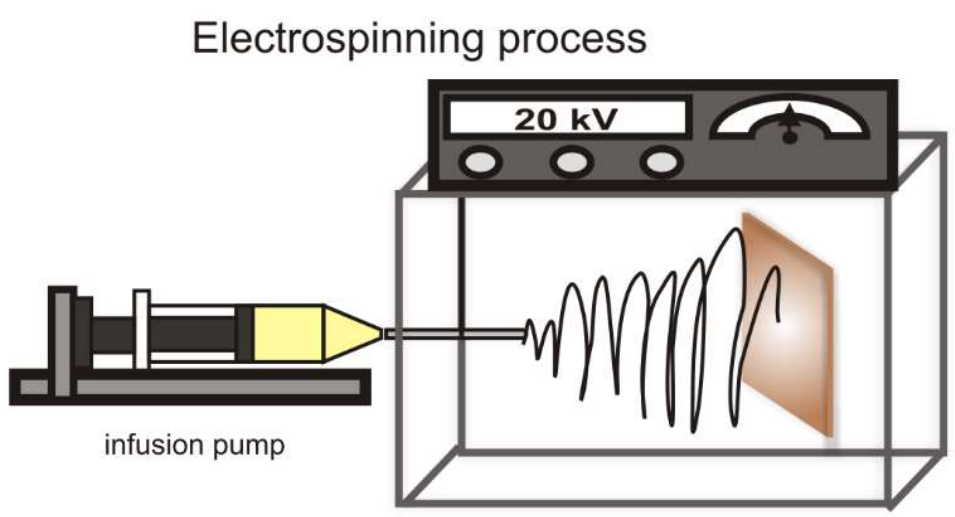

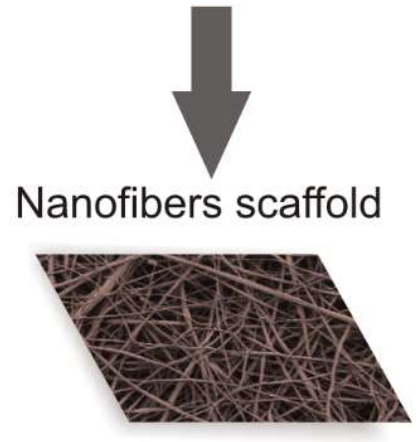

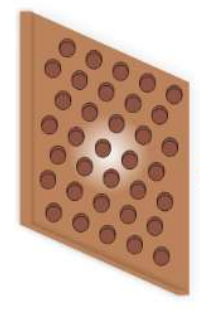

Drug release

Figure 3. In vivo analysis of drug loaded electrospun nanofibers 
Table 2. Examples of drug loaded electrospun nanofibers studied with animal models.

\begin{tabular}{|c|c|c|c|c|}
\hline Polymeric fiber & Drug & Application & Animal model & Ref. \\
\hline $\begin{array}{l}\text { Methacrylic acid copolymer } \\
\text { (EUDRAGIT® S100, MAC) }\end{array}$ & $\begin{array}{l}\text { Uranine (UN), } \\
\text { nifedipine (NP) }\end{array}$ & Anti-inflammatory & $\begin{array}{c}\text { Pharmacokinetic study in rats } \\
\text { after intraduodenal } \\
\text { administration }\end{array}$ & $(81)$ \\
\hline $\begin{array}{l}\text { Ethylcellulose (EC)- } \\
\text { core/Eudragit S100-shell } \\
\text { nanofibers }\end{array}$ & $\begin{array}{l}\text { Budesonide } \\
\text { (BUD) }\end{array}$ & Gastrointestinal & Gastrointestinal (GI) tract in rats & $(82)$ \\
\hline Poly (lactide) (PLA) & $\begin{array}{l}\text { Dichloroacetate } \\
\text { (DCA) }\end{array}$ & Anticancer & $\begin{array}{l}\text { Cervical carcinoma tumor- } \\
\text { bearing mice }\end{array}$ & $(83)$ \\
\hline $\begin{array}{l}\text { Poly (vinyl alcohol) (PVAL) and } \\
\text { sodium alginate (NaAlg) }\end{array}$ & $\begin{array}{l}\text { Ciprofloxacin } \\
\text { (CIP) }\end{array}$ & Antimicrobial & $\begin{array}{l}\text { Transdermal tissue of male } \\
\text { rabbits }\end{array}$ & $(84)$ \\
\hline
\end{tabular}

Table 3. Examples of drug loaded electrospun nanofibers studied with human volunteers.

\begin{tabular}{|c|c|c|c|c|c|}
\hline Polymeric fiber & Drug & Application & $\begin{array}{c}\text { No. of } \\
\text { volunteers }\end{array}$ & Characteristics tested & Ref. \\
\hline $\begin{array}{l}\text { Thiolated chitosan (CS-SH) } \\
\text { blended with poly (vinyl } \\
\text { alcohol) (PVAL) }\end{array}$ & $\begin{array}{c}\alpha- \\
\text { Mangostin }\end{array}$ & $\begin{array}{l}\text { Oral care and } \\
\text { prevention of } \\
\text { dental caries }\end{array}$ & 6 & $\begin{array}{l}\text { Antibacterial activity, } \\
\text { mucoadhesive property, } \\
\text { and taste and mouth feel } \\
\text { of the nanofiber mats. }\end{array}$ & $(86)$ \\
\hline $\begin{array}{c}\text { Poly (vinyl pyrrolidone) } \\
\text { (PVP), Poly (ethylene oxide) } \\
\text { (PEO), poly (caprolactone) } \\
\text { (PCL) }\end{array}$ & $\begin{array}{l}\text { Clobetasol- } \\
17- \\
\text { propionate }\end{array}$ & $\begin{array}{l}\text { Treatment of oral } \\
\text { lichen planus } \\
(\text { OLP) and } \\
\text { recurrent aphthous } \\
\text { stomatitis (RAS) }\end{array}$ & 26 & Patch adhesion & $(87)$ \\
\hline $\begin{array}{c}\text { Poly (methyl } \\
\text { vinyl ether-alt-maleic ethyl } \\
\text { monoester) (PMVEMA-ES) }\end{array}$ & $\begin{array}{l}\text { Salicylic } \\
\text { acid, methyl } \\
\text { salicylate, } \\
\text { and } \\
\text { capsaicin }\end{array}$ & Psoriasis treatment & 3 & $\begin{array}{c}\text { Functionality of the } \\
\text { encapsulated TRPV1 } \\
\text { agonists by analyzing its } \\
\text { responsiveness }\end{array}$ & $(88)$ \\
\hline Poly (vinyl-alcohol) (PVAL) & $\begin{array}{l}\text { Donepezil } \\
\mathrm{HCl}\end{array}$ & Dysphagia & 1 & $\begin{array}{c}\text { Time of disappearance of } \\
\text { the web }\end{array}$ & (89) \\
\hline Poly (ethylene oxide) (PEO) & Chitosan & $\begin{array}{l}\text { Treatment of II, } \\
\text { IIIa, and IIIb } \\
\text { degree burns }\end{array}$ & $\begin{array}{l}19 \text { (II), } 10 \\
\text { (IIIa), } 10 \\
\text { (IIIb) }\end{array}$ & Wound-healing behavior & $(90)$ \\
\hline
\end{tabular}

The electrospinning technique has gained importance in the pharmaceutical industry as an alternative strategy to develop a new form to administrate and transport pharmaceutical drugs. Nano- or microfibers produced by this technique possess some interesting advantages over the other methods of administration. Their intrinsic high surface area-to-volume ratio, the versatility of fiber composition, their surface bioactivity, the manipulation of the drug release rate, their easy fabrication and cost-effectiveness operation are all attractive features for their drug delivery application.

This review presented many examples of poorly water soluble drugs being loaded into hydrophilic polymeric fibers, which were successfully incorporated and released at desired times. Some of the presented works reported time stable drug loaded fibers, focusing on the importance of drug administration system storage and transport.

It has been demonstrated that hydrophilic fibers increase drug dissolution, and for instance bioavailability. In the case of electrospun scaffolds, fast release formulations for oral absorption are specially of interest to avoid first pass metabolism and degradation in gastric fluids. Moreover, the present review summarizes most of the antiinflammatory, anti-histaminic, gastrointestinal, cardiovascular, contraceptive, anti-cancer, anti- 
microbial, palliative and miscellaneous drug that have been loaded into nanofibers.

Besides electrospinning, other techniques have been tested to produce drug loaded mats for oral distribution, but electrospun nanofibers have demonstrated to be the most efficient. In the case of electrospinning, this technique possesses different configurations as single needle electrospinning, high speed electrospinning, coaxial electrospinning and electrospraying, that allow for the production of versatile fiber configurations that can improve the release and protection of the pharmaceutical drug.

Until now, most studies on the release of pharmaceutical agents are carried out in vitro. In the case of in vivo studies, few literature have been reported. Most of the nanofibers have been implanted in rodents. It is for sure that in-depth systemic studies are necessary before any clinical marketing is considered, especially those on the kinetics and dynamics of drug release in vivo, the effects of drug dosage and release kinetics on therapeutic efficacy, and the biodistribution of the released drugs. Full studies are indispensable about toxic effects over long periods of time, as well as pharmacokinetics of the polymeric transporters.

\section{ACKNOWLEDGEMENTS}

The authors are grateful to the "Consejo Nacional de Ciencia y Tecnología (CONACYT)" grant known as "Fondo de Cooperación Internacional en Ciencia y Tecnología del Conacyt (FONCICYT)" and grant named "Convocatoria Conjunta de Movilidad 2015 CONACYT-DST México-India" with CONACYT project number 266380 and SICASPI-UABC number 351/375/E and PAPIIT IN-108116, UNAM.

\section{REFERENCES}

1. Huang, Z.-M.; Zhang, Y.-Z.; Kotaki, M.; Ramakrishna, S. A review on polymer nanofibers by electrospinning and their applications in nanocomposites. Compos. Sci. Technol. 2003, 63 (15), 2223-2253 DOI: 10.1016/S0266-3538(03)00178-7.

2. Villarreal-Gómez, L.J.; Vera-Graziano, R.; VegaRíos, M.R.; Pineda-Camacho, J.L.; Almanza-Reyes, H.; Mier-Maldonado, P.A.; Cornejo-Bravo, J.M. Biocompatibility evaluation of electrospun scaffolds of poly (L-lactide) with pure and grafted hydroxyapatite. J Mex Chem Soc. 2014, 58(4):43543.

DOI:

http://www.scielo.org.mx/scielo.php?script=sci_artte

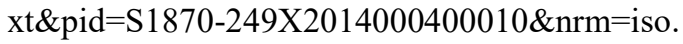

3. Morais, J.M.; Papadimitrakopoulos, F.; Burgess, D.J. Biomaterials/tissue interactions: possible solutions to overcome foreign body response. The AAPS Journal. 2010, 12(2): 188-196. doi:10.1208/s12248-0109175-3.

4. Tucker, N.; Stanger, J.; Staiger, M.; Razzaq, H.; Hofman, K. The history of the science and technology of electrospinning from 1600 to 1995. J. Eng. Fiber. Fabr. 2012, 7 (Special Issue), 63-73.

5. Fernández de la Mora, J. The fluid dynamics of Taylor cones. Annu. Rev. Fluid Mech. 2007, 39 (1), 217-243

DOI: 10.1146/annurev.fluid.39.050905.110159.

6. Cornejo Bravo, J. M.; Villarreal Gómez, L. J.; Serrano Medina, A. Electrospinning for drug delivery systems: drug incorporation techniques. In Electrospinning - Material, Techniques, and Biomedical Applications; InTech, 2016; p 14.

7. Singh, H.; Sharma, R.; Joshi, M.; Garg, T.; Goyal, A. K.; Rath, G. Transmucosal delivery of docetaxel by mucoadhesive polymeric nanofibers. Artif. Cells, Nanomedicine, Biotechnol. 2015, 43 (4), 263-269 DOI: 10.3109/21691401.2014.885442.

8. Velasco Barraza, R. Designing a low cost electrospinning device for practical learning in a bioengineering biomaterials course. Rev. Mex. Ing. Biomédica 2016, 37 (1), 27-36 DOI: 10.17488/RMIB.37.1.1.

9. Villarreal-Gómez, L. J.; Cornejo-Bravo, J. M.; VeraGraziano, R.; Grande, D. Electrospinning as a powerful technique for biomedical applications: a critically selected survey. J. Biomater. Sci. Polym. Ed. 2016, $27 \quad$ (2), 157-176 DOI: 10.1080/09205063.2015.1116885.

10. Tam, S.K.; Dusseault, J.; Bilodeau, S.; Langlois, G.; Hallé, J.P.; Yahia, L. Factors influencing alginate gel biocompatibility. J Biomed Mater Res A. 2011, 98(1): 40-52. doi: 10.1002/jbm.a.33047.

11. Rottensteiner, U.; Sarker, B.; Heusinger, D.; Dafinova, D.; Rath, S.N.; Beier, J.P.; Kneser, U.; Horch, R.E.; Detsch, R.; Boccaccini, A.R.; Arkudas, A. In vitro and in vivo biocompatibility of alginate dialdehyde/gelatin hydrogels with and without nanoscaled bioactive glass for bone tissue engineering applications. Mater. 2014, 7(3): 19571974. doi:10.3390/ma7031957.

12. Rodrigues, S.; Dionísio, M.; Remuñán-López, C., Grenha, A. Biocompatibility of chitosan carriers with application in drug delivery. J Funct Biomater. 2012, 3(3): 615-641. doi:10.3390/jfb3030615.

13. Yamada, S.; Yamamoto, K.; Ikeda, T.; Yanagiguchi, K.; Hayashi, Y. Potency of fish collagen as a scaffold for regenerative medicine. BioMed Res Int. 2014, 2014: 302932. doi:10.1155/2014/302932.

14. Zhang, Y.; Sun, T.; Jiang, C. Biomacromolecules as carriers in drug delivery and tissue engineering. Acta Pharm Sin B. 2018, 8(1): 34-50. 
doi:10.1016/j.apsb.2017.11.005.

15. Sun, G.; Mao, J.J. Engineering dextran-based scaffolds for drug delivery and tissue repair. Nanomedicine. 2012, 7(11): 1771-1784. doi:10.2217/nnm.12.149.

16. Khalikova, E.; Susi, P.; Korpela, T. Microbial dextran-hydrolyzing enzymes: fundamentals and applications. Microbiol Mol Biol Rev. 2005, 69(2): 306-325. doi:10.1128/MMBR.69.2.306-325.2005.

17. Khunmanee, S.; Jeong, Y.; Park, H. Crosslinking method of hyaluronic-based hydrogel for biomedical applications. $J$ Tissue Eng. 2017, 8: 2041731417726464. doi:10.1177/2041731417726464.

18. Lam, J.; Truong, N.F.; Segura. T. Design of cellmatrix interactions in hyaluronic acid hydrogel scaffolds. Acta Biomater. 2014, 10(4): 1571-1580. doi:10.1016/j.actbio.2013.07.025.

19. Gardner, A.B.; Lee, S. K. C.; Woods, E.C.; Acharya, A.P. Biomaterials-based modulation of the immune system. BioMed Res. Int. 2013, 732182, 1-7. https://doi.org/10.1155/2013/732182.

20. Yu, D.-G.; Shen, X.-X.; Branford-White, C.; White, K.; Zhu, L.-M.; Annie Bligh, S. W. Oral fastdissolving drug delivery membranes prepared from electrospun polyvinylpyrrolidone ultrafine fibers. Nanotechnology 2009, 20 (5), 55104 DOI: 10.1088/0957-4484/20/5/055104.

21. Wu, Y. H.; Yu, D. G.; Li, H. C.; Feng, D. N. Electrospun nanofibers for fast dissolution of naproxen prepared using a coaxial process with ethanol as a shell fluid. Appl. Mech. Mater. 2014, 662, 29-32

DOI:

10.4028/www.scientific.net/AMM.662.29.

22. Lopez, F. L.; Shearman, G. C.; Gaisford, S.; Williams, G. R. Amorphous formulations of indomethacin and griseofulvin prepared by electrospinning. Mol. Pharm. 2014, 11 (12), 4327-4338 DOI: $10.1021 / \mathrm{mp} 500391 \mathrm{y}$.

23. Samprasit, W.; Akkaramongkolporn, P.; Ngawhirunpat, T.; Rojanarata, T.; Kaomongkolgit, R.; Opanasopit, P. Fast releasing oral electrospun PVP/CD nanofiber mats of taste-masked meloxicam. Int. J. Pharm. 2015, 487 (1-2), 213-222 DOI: 10.1016/j.ijpharm.2015.04.044.

24. Um-I-Zahra, S.; Zhu, L. Novel drug loaded duplicate nanofibers and their in-vitro drug release profiles. $\mathrm{Am}$. Res. Thoughts 2015, 1 (6), 1683-1698.

25. Yu, D.-G.; Branford-White, C.; White, K.; Li, X.-L.; Zhu, L.-M. Dissolution improvement of electrospun nanofiber-based solid dispersions for acetaminophen. Am. Assoc. Pharm. Sci. 2010, 11 (2), 809-817 DOI: 10.1208/s12249-010-9438-4.

26. Akhgari, A.; Ghalambor Dezfuli, A.; Rezaei, M.; Kiarsi, M.; Abbaspour, M. The design and evaluation of a fast-dissolving drug delivery system for loratadine using the electrospinning method. Jundishapur J. Nat. Pharm. Prod. 2016, 11 (2) DOI: 10.17795/jjnpp-33613.

27. Sahoo, S.K.; Mallick, A.A.; Barik, B.B.; Senapati, P.C. Preparation and in vitro evaluation of ethyl cellulose microspheres containing stavudine by the double emulsion method. Pharmazie. 2007, 62(2): $117-21$. https://www.ncbi.nlm.nih.gov/pubmed/17341031.

28. Vigh, T.; Horváthová, T.; Balogh, A.; Sóti, P. L.; Drávavölgyi, G.; Nagy, Z. K.; Marosi, G. Polymerfree and polyvinylpirrolidone-based electrospun solid dosage forms for drug dissolution enhancement. Eur. J. Pharm. Sci. 2013, 49 (4), 595-602 DOI: 10.1016/j.ejps.2013.04.034.

29. Castillo-Ortega, M. M.; Montaño-Figueroa, A. G.; Rodríguez-Félix, D. E.; Munive, G. T.; HerreraFranco, P. J. Amoxicillin embedded in cellulose acetate-poly (vinyl pyrrolidone) fibers prepared by coaxial electrospinning: preparation and characterization. Mater. Lett. 2012, 76, 250-254 DOI: 10.1016/j.matlet.2012.02.093.

30. Yu, D.-G.; Zhu; Branford-White; Yang; Wang; Li; Qian. Solid dispersions in the form of electrospun core-sheath nanofibers. Int. J. Nanomedicine 2011, 6, 3271 DOI: $10.2147 /$ IJN.S27468.

31. Nagy, Z. K.; Nyúl, K.; Wagner, I.; Molnár, K.; Marosi, G. Electrospun water soluble polymer mat for ultrafast release of donepezil HCL. Express Polym. Lett. 2010, 4 (12), 763-772 DOI: 10.3144/expresspolymlett.2010.92.

32. Kadajji, V.G.; Betageri, G.V. Water soluble polymers for pharmaceutical applications. Polymers 2011, 3, 1972-2009.

33. Kenawy, E.-R.; Abdel-Hay, F. I.; El-Newehy, M. H.; Wnek, G. E. Controlled release of ketoprofen from electrospun poly(vinyl alcohol) nanofibers. Mater. Sci. Eng. A 2007, 459 (1-2), 390-396 DOI: 10.1016/j.msea.2007.01.039.

34. Li, X.; Kanjwal, M. A.; Lin, L.; Chronakis, I. S. Electrospun polyvinyl-alcohol nanofibers as oral fastdissolving delivery system of caffeine and riboflavin. Colloids Surfaces B Biointerfaces 2013, 103, 182188 DOI: $10.1016 /$ j.colsurfb.2012.10.016.

35. Gaaz, T.S.; Sulong, A.B.; Akhtar, M.N.; Kadhum, A.A.; Mohamad, A.B.; Al-Amiery, A.A. Properties and applications of polyvinyl alcohol, halloysite nanotubes and their nanocomposites. Molecules. 2015, 20(12): 22833-47. doi: 10.3390/molecules201219884.

36. Ball, C.; Krogstad, E.; Chaowanachan, T.; Woodrow, K. A. Drug-eluting fibers for HIV-1 inhibition and contraception. PLoS One 2012, 7 (11), e49792 DOI: 10.1371/journal.pone.0049792.

37. Xu, X.; Yang, L.; Xu, X.; Wang, X.; Chen, X.; Liang, Q.; Zeng, J.; Jing, X. Ultrafine medicated fibers electrospun from W/O emulsions. J. Control. Release 2005, $108 \quad$ (1), $33-42 \quad$ DOI: 10.1016/j.jconrel.2005.07.021. 
38. Xu, X.; Chen, X.; Wang, Z.; Jing, X. Ultrafine PEGPLA fibers loaded with both paclitaxel and doxorubicin hydrochloride and their in vitro cytotoxicity. Eur. J. Pharm. Biopharm. 2009, 72 (1), 18-25 DOI: 10.1016/j.ejpb.2008.10.015.

39. Mahalingam, R.; Jasti, B.; Birudaraj, R.; Stefanidis, D.; Killion, R.; Alfredson, T.; Anne, P.; Li, X. Evaluation of polyethylene oxide compacts as gastroretentive delivery systems. AAPS PharmSciTech. 2009, 10(1): 98-103. doi:10.1208/s12249-008-9182-1.

40. Potrč, T.; Baumgartner, S.; Roškar, R.; Planinšek, O.; Lavrič, Z.; Kristl, J.; Kocbek, P. Electrospun polycaprolactone nanofibers as a potential oromucosal delivery system for poorly water-soluble drugs. Eur. J. Pharm. Sci. 2015, 75, 101-113 DOI: 10.1016/j.ejps.2015.04.004.

41. Vrbata, P.; Berka, P.; Stránská, D.; Doležal, P.; Musilová, M.; Čižinská, L. Electrospun drug loaded membranes for sublingual administration of sumatriptan and naproxen. Int. J. Pharm. 2013, 457 (1), 168-176 DOI: 10.1016/j.jpharm.2013.08.085.

42. Canbolat, M. F.; Celebioglu, A.; Uyar, T. Drug delivery system based on cyclodextrin-naproxen inclusion complex incorporated in electrospun polycaprolactone nanofibers. Colloids Surfaces B Biointerfaces 2014, $115, \quad 15-21 \quad$ DOI: 10.1016/j.colsurfb.2013.11.021.

43. Hira, S.K.; Mishra, A.K.; Ray, B.; Manna, P.P. Targeted delivery of doxorubicin-loaded poly $(\varepsilon-$ caprolactone)-b-poly (N-vinylpyrrolidone) micelles enhances antitumor effect in lymphoma. Bansal $\mathrm{V}$, ed. PLoS ONE. 2014, 9(4): e94309. doi:10.1371/journal.pone.0094309.

44. Liu, H.; Tang, C. Electrospinning of cellulose acetate in solvent mixture $\mathrm{N}, \mathrm{N}$-dimethylacetamide (DMAc)/acetone. Polymer J. 2007, 39: 65-72. https://doi.org/10.1295/polymj.PJ2006117.

45. Karthikeyan, K.; Guhathakarta, S.; Rajaram, R.; Korrapati, P. S. Electrospun zein/eudragit nanofibers based dual drug delivery system for the simultaneous delivery of aceclofenac and pantoprazole. Int. J. Pharm. 2012, 438 (1-2), 117-122 DOI: 10.1016/j.ijpharm.2012.07.075.

46. Reda, R.I.; Wen, M.M.; El-Kamel, A.H. Ketoprofenloaded Eudragit electrospun nanofibers for the treatment of oral mucositis. Int J Nanomedicine. 2017, 12: 2335-2351. doi:10.2147/IJN.S131253.

47. Dott, C.; Tyagi, C.; Tomar, L. K.; Choonara, Y. E.; Kumar, P.; du Toit, L. C.; Pillay, V. A mucoadhesive electrospun nanofibrous matrix for rapid oramucosal drug delivery. J. Nanomater. 2013, 2013, 1-19 DOI: 10.1155/2013/924947.

48. Aydogdu, A.; Sumnu, G.; Sahin, S. A novel electrospun hydroxypropyl methylcellulose/polyethylene oxide blend nanofibers: morphology and physicochemical properties.
Carbohydr Polym. 2018, 181: 234-246. https://doi.org/10.1016/j.carbpol.2017.10.071.

49. Buschle-Diller, G.; Cooper, J.; Xie, Z.; Wu, Y.; Waldrup, J.; Ren, X. Release of antibiotics from electrospun bicomponent fibers. Cellulose 2007, 14 (6), 553-562 DOI: 10.1007/s10570-007-9183-3.

50. Simamora, P.; Chern, W. Poly-L-lactic acid: an overview. J Drugs Dermatol. 2006, 5(5): 436-40. https://www.ncbi.nlm.nih.gov/pubmed/16703779.

51. Gentile, P.; Chiono, V.; Carmagnola, I.; Hatton, P.V. An overview of poly (lactic-co-glycolic) acid (PLGA)-based biomaterials for bone tissue engineering. Int J Mol Sci. 2014, 15(3): 3640-3659. doi:10.3390/ijms15033640.

52. Chen, H.-M.; Yu, D.-G. An elevated temperature electrospinning process for preparing acyclovirloaded PAN ultrafine fibers. J. Mater. Process. Technol. 2010, 210 (12), 1551-1555 DOI: 10.1016/j.jmatprotec.2010.05.001.

53. Sinha, M.K.; Das, B.R.; Srivastava, A.; Saxena, A.K. Study of electrospun polylacrylonitrile (PAN) and PAN/CNT composite nanofibrous webs. Res J Textile Apparel 2015, 19 (1): 36-45. https://doi.org/10.1108/RJTA-19-01-2015-B004.

54. Nagy, Z. K.; Balogh, A.; Démuth, B.; Pataki, H.; Vigh, T.; Szabó, B.; Molnár, K.; Schmidt, B. T.; Horák, P.; Marosi, G.; et al. High speed electrospinning for scaled-up production of amorphous solid dispersion of itraconazole. Int. J. Pharm. 2015, 480 (1-2), $137-$ 142 DOI: 10.1016/j.ijpharm.2015.01.025.

55. Verreck, G.; Chun, I.; Rosenblatt, J.; Peeters, J.; Dijck, A. Van; Mensch, J.; Noppe, M.; Brewster, M. E. Incorporation of drugs in an amorphous state into electrospun nanofibers composed of a waterinsoluble, nonbiodegradable polymer. J. Control. Release 2003, 92 (3), 349-360 DOI: 10.1016/S01683659(03)00342-0.

56. Nangrejo, M.; Bragmana, F.; Ahmad, Z.; Stride, E.; Edirisinghe, M. Hot electrospinning of polyurethane fibres. Mater. Letters 2012, 68: 482-485. https://doi.org/10.1016/j.matlet.2011.11.019.

57. Huang, Z.-M.; He, C.-L.; Yang, A.; Zhang, Y.; Han, X.-J.; Yin, J.; Wu, Q. Encapsulating drugs in biodegradable ultrafine fibers through co-axial electrospinning. J. Biomed. Mater. Res. Part A 2006, 77A (1), 169-179 DOI: 10.1002/jbm.a.30564.

58. Shrestha, R.; Palat, A.; Punnoose, A.M.; Joshi, S.; Solomon, P.; Paula, F.D. Electrospun cellulose acetate phthalate nanofibrous scaffolds fabricated using novel solvent combinations biocompatible for primary chondrocytes and neurons. Tissue Cell. 2016, $48 \quad$ (6): 634-643. https://doi.org/10.1016/j.tice.2016.07.007.

59. Torres-Martinez, E,J.; Cornejo Bravo, J.M.; Serrano Medina, A.; Pérez González, G.L.; Villarreal Gómez LJ. A summary of electrospun nanofibers as drug delivery system: drugs loaded and biopolymers used 
as matrices. Curr Drug Deliv. 2018, 15(10): 13601374. DOI: $10.2174 / 1567201815666180723114326$.

60. Topuz, F.; Uyar, T. Electrospinning of cyclodextrin functional nanofibers for drug delivery applications. Pharmaceutics 2019, 11(1): 6; https://doi.org/10.3390/pharmaceutics11010006.

61. Buer, J. K. Origins and impact of the term "NSAID." Inflammopharmacology 2014, 22 (5), 263-267 DOI: 10.1007/s10787-014-0211-2.

62. Goodman, L. S.; Brunton, L. L.; Chabner, B.; Knollmann, B. C. Goodman \& Gilman's pharmacological basis of therapeutics.; McGrawHill: New York, 2011.

63. Yu, D.-G.; Zhang, X.-F.; Shen, X.-X.; BrandfordWhite, C.; Zhu, L.-M. Ultrafine ibuprofen-loaded polyvinylpyrrolidone fiber mats using electrospinning. Polym. Int. 2009, 58 (9), 1010-1013 DOI: 10.1002/pi.2629.

64. Quan, J.; Yu, Y.; Branford-White, C.; Williams, G. R.; Yu, D.-G.; Nie, W.; Zhu, L.-M. Preparation of ultrafine fast-dissolving feruloyl-oleyl-glycerolloaded polyvinylpyrrolidone fiber mats via electrospinning. Colloids Surfaces B Biointerfaces 2011, 88 (1), 304-309 DOI: 10.1016/j.colsurfb.2011.07.006.

65. Karmoker, J. R.; Sarkar, S.; Joydhar, P.; Chowdhury, S. F. Comparative in vitro equivalence evaluation of some Aceclofenac generic tablets marketed in Bangladesh. Pharma Innov. J. TPI 2016, 5 (3), 3-7 DOI:

http://www.thepharmajournal.com/archives/2016/vo 15issue3/PartA/5-1-7.pdf.

66. Tyagi, C.; Tomar, L.; Choonara, Y. E.; Toit, L. C. Du; Kumar, P.; Pillay, V. Electrospun nanofiber matrix with a mucoadhesive backing film for oramucosal drug delivery. Int. J. Mater. Mech. Manuf. 2014, 2 (1), 81-85 DOI: 10.7763/IJMMM.2014.V2.105.

67. Zitek, T.; Gates, M.; Pitotti, C.; Bartlett, A.; Patel, J.; Rahbar, A.; Forred, W.; Sontgerath, J. S.; Clark, J. M. A Comparison of headache treatment in the emergency department: prochlorperazine versus ketamine. Ann. Emerg. Med. 2017, 1-10 DOI: 10.1016/j.annemergmed.2017.08.063.

68. Jaber, B. M.; Petroianu, G. A.; Rizvi, S. A.; Borai, A.; Saleh, N. A.; Hala, S. M.; Saleh, A. M. Protective effect of metoclopramide against organophosphateinduced apoptosis in the murine skin fibroblast L929. J. Appl. Toxicol. 2017, n/a--n/a DOI: 10.1002/jat.3543.

69. Tiwari, S. K.; Tzezana, R.; Zussman, E.; Venkatraman, S. S. Optimizing partition-controlled drug release from electrospun core-shell fibers. Int. J. Pharm. 2010, 392 (1-2), 209-217 DOI: 10.1016/j.ijpharm.2010.03.021.

70. Singh, B.; Garg, T.; Goyal, A. K.; Rath, G. Development, optimization, and characterization of polymeric electrospun nanofiber: a new attempt in sublingual delivery of nicorandil for the management of angina pectoris. Artif. Cells, Nanomedicine, Biotechnol. 2015, No. April, 1-10 DOI: 10.3109/21691401.2015.1052472.

71. Maton, A. Human Biology and Health; Prentice Hall science; Pearson Prentice Hall, 1997.

72. Blakney, A.; Jiang, Y.; Woodrow, K.; Krogstad, E. Delivery of multipurpose prevention drug combinations from electrospun nanofibers using composite microarchitectures. Int. J. Nanomedicine 2014, 9, 2967 DOI: 10.2147/IJN.S61664.

73. Zhang, Y.; Liu, S.; Wang, X.; Zhang, Z.; Jing, X. Prevention of local liver cancer recurrence after surgery using multilayered cisplatin-loaded polylactide electrospun nanofibers. 2014, 32 (8), 1111-1118 DOI: 10.1007/s10118-014-1491-0.

74. Salehi, R.; Irani, M.; Rashidi, M.-R.; Aroujalian, A.; Raisi, A.; Eskandani, M.; Haririan, I.; Davaran, S. Stimuli-responsive nanofibers prepared from poly (N-isopropylacrylamide-acrylamide-

vinylpyrrolidone) by electrospinning as an anticancer drug delivery. Des. Monomers Polym. 2013, 16 (6), 515-527 DOI: 10.1080/15685551.2013.771303.

75. Katzung, B. G.; Masters, S. B.; Trevor, A. J. Basic \& clinical pharmacology; McGraw-Hill Medical; McGraw-Hill (distributor): New York; London, 2012.

76. Xie, J.; Wang, C.-H. Electrospun micro- and nanofibers for sustained delivery of paclitaxel to treat C6 glioma in vitro. Pharm. Res. 2006, 23 (8), 18171826 DOI: 10.1007/s11095-006-9036-z.

77. Modgill, V.; Garg, T.; Goyal, A. K.; Rath, G. Permeability study of ciprofloxacin from ultra-thin nanofibrous film through various mucosal membranes. Artif. Cells, Nanomedicine, Biotechnol. 2016, $44 \quad$ (1), $122-127 \quad$ DOI: 10.3109/21691401.2014.924007.

78. He, C.; Huang, Z.; Han, X.; Liu, L.; Zhang, H.; Chen, L. Coaxial electrospun poly (L -lactic acid) ultrafine fibers for sustained drug delivery. J. Macromol. Sci. Part $B$ 2006, 45 (4), 515-524 DOI: 10.1080/00222340600769832.

79. Borbás, E.; Balogh, A.; Bocz, K.; Müller, J.; Kiserdei, É.; Vigh, T.; Sinkó, B.; Marosi, A.; Halász, A.; Dohányos, Z.; et al. In vitro dissolution-permeation evaluation of an electrospun cyclodextrin-based formulation of aripiprazole using $\mu \mathrm{Flux}^{\mathrm{TM}}$. Int. J. Pharm. 2015, 491 (1-2), 180-189 DOI: 10.1016/j.ijpharm.2015.06.019.

80. Kim, S.; Thiessen, P.A.; Bolton, E.E.; Chen, J.; Fu, G.; Gindulyte, A.; Han, L.; He, J.; He, S.; Shoemaker, B.A.; Wang, J.; Yu, B.; Zhang, J.; Bryant, S.H. PubChem substance and compound databases. Nucleic Acids Res. 2016, 44(D1): D1202-13. doi: 10.1093/nar/gkv951.

81. Hamori, M.; Yoshimatsu, S.; Hukuchi, Y.; Shimizu, Y.; Fukushima, K.; Sugioka, N.; Nishimura, A.; Shibata, N. Preparation and pharmaceutical 
evaluation of nano-fiber matrix supported drug delivery system using the solvent-based electrospinning method. Int J Pharm. 2014, 464 (12): 243-251. https://doi.org/10.1016/j.ijpharm.2013.12.036.

82. Xu, Q.; Zhang, N.; Qin, W.; Liu, J.; Jia, Z.; Liu, H. Preparation, in vitro and in vivo evaluation of budesonide loaded core/shell nanofibers as oral colonic drug delivery system. J Nanosci Nanotechnol. 2013, 13(1): 149-56. https://www.ncbi.nlm.nih.gov/pubmed/23646710.

83. Liu, D.; Liu, S.; Jing, X.; Li, X.; Li, W.; Huang, Y. Necrosis of cervical carcinoma by dichloroacetate released from electrospun polylactide mats. Biomater. 2012, 33(17): 4362-9. doi: 10.1016/j.biomaterials.2012.02.062.

84. Kataria, K.; Gupta, A.; Rath, G.; Mathur, R. B.; Dhakate, S.R. In vivo wound healing performance of drug loaded electrospun composite nanofibers transdermal patch. Int J Pharm. 2014, 469(1): 102-10. doi: 10.1016/j.ijpharm.2014.04.047.

85. Persano, L.; Camposeo, A.; Tekmen, C.; Pisignano, D. Industrial upscaling of electrospinning and applications of polymer nanofibers: a aeview. Macromol Mater Eng. 2013, 298(5): 504-520. https://doi.org/10.1002/mame.201200290.

86. Samprasit, W.; Rojanarata, T.; Akkaramongkolporn, P.; Ngawhirunpat, T.; Kaomongkolgit, R.; Opanasopit; P. Fabrication and In vitro/In vivo performance of mucoadhesive electrospun nanofiber mats containing $\alpha$-mangostin. AAPS PharmSciTech. 2015, 16(5): 1140-1152. doi:10.1208/s12249-015$0300-6$.

87. Colley, H.E.; Said, Z.; Santocildes-Romero, M.E.; Baker, S.R.; D'Apice, K.; Hansen, J.; Siim Madsen, L.; Thornhill, M.H.; Hatton, P.V.; Murdoch, C. Preclinical evaluation of novel mucoadhesive bilayer patches for local delivery of clobetasol-17-propionate to the oral mucosa. Biomater. 2018, 178(1): 134-146. https://doi.org/10.1016/j.biomaterials.2018.06.009.

88. Martínez-Ortega, L.; Mira, A.; Fernandez-Carvajal, A.; Reyes Mateo, C.; Mallavia, R.; Falco, A. Development of a new delivery system based on drug-loadable electrospun nanofibers for psoriasis treatment. Pharmaceutics 2019, 11: 1-14. doi:10.3390/pharmaceutics11010014.

89. Nagy, Z.K.; Nyúl, K.; Wagner, I.; Molnár, K.; Marosi, G. Electrospun water soluble polymer mat for ultrafast release of Donepezil HCl. eXPRESS Polym Lett. 2010, 4 (12): 763-772. DOI: 10.3144/expresspolymlett.2010.92.

90. Kossovich, L.Y.; Salkovskiy, Y.; Kirillova, I.V. Electrospun chitosan nanofiber materials as burn dressing. In: Lim C.T., Goh J.C.H. (eds) 6th World Congress of Biomechanics (WCB 2010). August 1-6, 2010 Singapore. IFMBE Proceedings, vol 31. Springer, Berlin, Heidelberg. https://doi.org/10.1007/978-3-642-14515-5_307. 